\title{
Molecular and genetic approaches for investigation of phospholipase D role in plant cells
}

\author{
V. S. Kravets, Ya. S. Kolesnikov, S. V. Kretynin, E. M. Kabachevskaya', \\ G. V. Liahnovitch', O. M. Bondarenko, I. D. Volotovsky, V. P. Kukhar
}

Institute of Bioorganic Chemistry and Petrochemistry, NAS of Ukraine 1 Murmanska Str., 02660, Kyiv, Ukraine

${ }^{1}$ Institute of Biophysics and Cell Engineering, NAS of Belarus

27 Akademicheskaya Str., Minsk BY-220072, Republic of Belarus

kravets@bpci.kiev.ua

The review is devoted to the analysis of publications concerning the role of phospholipase D (PLD) in
regulation of metabolism in plant cells. Analysis of molecular and genetic studies suggest that PLD is an
important component of various hormonal and stress signaling pathways. Keywords: phospholipase D, phosphatidic acid, transgenic plants.

The cognition of the nature of intracellular signaling and its role in the regulation of cell metabolism is one of intensively developing trends of modern biology. The results of investigations on signaling systems of plant cells testify to the fact that phospholipids (PL) are not just structural components of membranes, but also precursors of second messengers of intracellular signaling. Many stresses and a number of phytohormones cause sharp increase in the content of phosphatidic acid (PA) in plant cells which proves activation of phospholipases, in particular,

\footnotetext{
(C) Institute of Molecular Biology and Genetics NAS of Ukraine, 2010
}

phospholipase D, (PLD, EC 3.1.4.4). PLD is an enzyme, wide-spread in both plant and animal kingdoms, which hydrolyzes structural PL via terminal phosphodiester bond with subsequent formation of PA and free functional groups [1]. Together with primary alcohols PLD also catalyzes the reaction of transesterification with the formation of phosphatidyl alcohols (phosphatidylbutanol, in particular) [2] - the compounds which are successfully used for studying PLD activity in vivo. Twelve genes of various isoenzymes of PLD - PLD $\alpha$ (3), $\beta(2), \gamma(3), \delta, \varepsilon$ and $\xi$ (2) [3] were cloned in Arabidopsis thaliana. Seventeen genes of this enzyme were coded in the genome of rice 


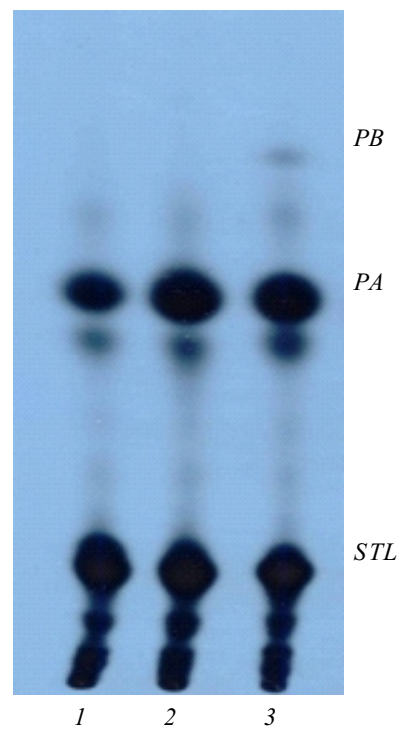

Fig. 1. Radioautograph of phospholipids of amaranthus tissues. The influence of BAP $(10 \mathrm{~min})$ in vivo on the synthesis of phosphatidylbutanol by PLD: 1 - control; 2 - 1-butanol; 3 - BAP + 1-butanol (PB - phosphatidylbutanol; PA - phosphatidic acid; STL structural phospholipids)

- PLD $\alpha(8), \beta(2), \delta(3), \kappa, \xi(2)$ and $\phi[4]$. The activity of PLD was first registered in 1947 in extracts of carrot roots as an enzyme, hydrolyzing lecitin (phosphatidylcholine) in PL mixtures [5]. Later PLD was found in cells of animals, fungi, and bacteria [6].

At present the attention of scientists is focused upon the study of mechanisms of PLD participation in signaling cascades of cells in the process of regulation of cell metabolism of animals and plants [7]. PLD plays an important role in many physiological processes, such as germination, growth, senescence of plants and ripening of fruit, as well as in responses to the action of stresses and phytohormones [8,9].

The investigation on the structure of genes and proteins of PLD involves various genetic manipulations with this enzyme which are an essential stage in the determination of its role and functions in cells and plant organism as a whole. An analysis of growth and development of plant lines with PLD deficiency as well as of mutants with T-DNA, inserted in PLD genes, allows defining the significance of various isoenzymes of PLD in the regulation of metabolism in response to the activity of many hormones and stresses. The construction of transgenic plants with simultaneous knockout of genes of several
PLD isoenzymes permits to obtain a phenotype, which is more expressed compared to that of mutants with the knockout of a specific gene, and to reveal a PLD function not found before.

Genetic engineering methods in study on PLD role in biological activity of cytokinins and abscisic acid. The study of molecular mechanisms of hormone signal transduction, including the action of cytokinins, is an important part in the investigation of regulation of cell metabolism [10-15]. Specific bioassays are widely used to reveal possible ways of phytohormone activity. In cotyledons of etiolated seedlings of amaranthus (Amaranthus caudatus L.), exogenously introduced cytokinin 6-benzylaminopurine (BAP) induces rapid accumulation of a red pigment amaranthin, which serves as a basis of specific sensitive and reliable bioassay for the activity of this phytohormone [11, 12]. The substances which are inhibitors of intracellular signal transmission, decreasing the level of amaranthin biosynthesis, are used to reveal the mechanisms of cytokinin activity in cells. The treatment of plants with primary alcohols (1-butanol, in particular), inhibitors of PA formation, catalyzed by PLD, decreases the level of pigment biosynthesis earlier than transcription blockers. Furthermore, primary alcohols (contrary to the secondary ones) block the accumulation of transcripts of primary response gene to cytokinins [11-13]. In the cells of periwinkle the stimulating effect of cytokinins on the transcription of primary response genes is also evidently inhibited by primary alcohols. However, their application together with PA results in restoration of induction by cytokinins of the transcription of cytokinins primary response gene [14]. The analysis of PL content in corn coleoptiles testifies that the 30-min treatment of sprouts with BAP results in 3-fold increase in concentrations of PA and products of PLD-catalyzed hydrolysis reaction, and in decrease in the amount of phosphatidylethanolamine, the substrate of this enzyme [15]. We have demonstrated that PLD is involved in the signaling cascade of cytokinins in plant cells $[12,13]$. An application of BAP together with 1-butanol in amaranthus tissues induced the phosphatidylbutanol synthesis, catalyzed by PLD (Fig.1). Further studies using transgenic plants will allow revealing PLD isoenzyme, playing a significant role in the signaling cascade of cytokinins. 
Abscisic acid (ABA) is a phytohormone, mediating the reaction of plant metabolism to water deficiency [16]. PLD plays a key role in the induction of stomata closure, conditioned by ABA. Upon knockout and knockdown of PLDal, stomata of Arabidopsis do not close under the influence of this phytohormone, while the application of PA provokes their closure [16]. Artificial increase in $P L D \alpha 1$ gene expression results in increasing stomata sensitivity to ABA [16]. Arabidopsis plants, which are $P L D \alpha 1$ gene knockout, do not demonstrate any increase in the levels of PA and phosphatidylbutanol upon hydrolysis of phosphatidylcholine, stimulated by ABA [16]. The analysis of PA, formed under the influence of ABA at $P L D \alpha 1$ knockout, testifies to the fact that PLD 1 determines rapid increase in the content levels of various types of phosphatidic acids in the cells of leaves in response to this phytohormone [17]. Protein phosphatase ABI1 is a negative regulator of ABA signal transduction, blocking the expression of genes in the nucleus of cells, which are sensitive to this phytohormone. ABA stimulates the binding of ABI1 to plasmatic membrane and inhibition of activity of this enzyme, ensured by PA. In Arabidopsis plants, which are $P L D \alpha 1$ gene knockout, PA does not bind to protein phosphatase ABI1 and translocation of ABI1 to plasmatic membranes does not occur which results in accumulation of this protein in nuclei of cells [16]. ABA stimulates PLD $\alpha 1$, thus activating the biosynthesis of $\mathrm{PA}$, which bind and inhibit ABI1, that, in its turn, induces the expression of genes of response to ABA. It was revealed that mutant $p l d \alpha 1$ is not sensitive to ABA in the process of activation of stomata closure and inhibition of their opening. However, in double knockout mutant (of genes PLD and ABI1) pld $\alpha$ labil ABA does not inhibit the opening of guard cell aperture, but stimulates its closure. This may be explained by the removal of inhibiting effect of ABI1 on closure of stomata, stimulated by ABA. Taking the abovementioned into consideration, it can be stated that at knockout of $A B I 1$ and $P L D \alpha 1$ genes the signaling cascade of stomata closure is inactivated, but the mechanism of suppression of their opening is inhibited $[16,18]$.

PLD $\alpha 1$ binds to 6 -subunit of heterotrimeric G-protein (GPA1) [19, 20]. The transgenic Arabidopsis plants with mutations in pld $\alpha 1$ and gpal genes are characterized by increased loss of water in leaves. Considerably weakened sensitivity to ABA influence in the processes of induction of closure and blocking opening of guard cell apertures was registered in double mutant pld $\alpha$ lgpal similarly to phenotype of plants pld $\alpha 1$ [18]. The plants expressing PLD, which is not capable of binding to $\alpha$-subunit of heterotrimeric G-protein $\left(P L D \alpha 1_{K 5644}\right)$, are more susceptible to the inhibition of opening of guard cell aperture, stimulated by ABA, compared to the wild type plants. However, $P L D \alpha 1_{K 564 A}$ plants are characterized by normal sensitivity to ABA in the process of stimulation of stomata closure. This testifies to the fact that weakening of PLD $\alpha 1$ interaction with GPA1, resulting in their activation [20], causes the increase in response to abscisic acid in the process of inhibition of stomata opening, not affecting the closure of guard cell aperture, induced by ABA. The plants with knockout of gene of $\alpha$-subunit of heterotrimeric G-protein (gpal) and double mutants pldalgpal demonstrate only stimulation of stomata closure upon the application of PA. This phospholipid blocks stomata opening in pldal-plants contrary to mutants gpal and pldalgpal [18].

Therefore, in the absence of $\alpha$-subunit of hetero-three-dimensional G-protein, PLD is not capable of implementing ABA action on the blockade of stomata closure. Thus, PLD $\alpha 1$ and PA in mechanisms of regulation of stomata dynamics function prior to GPA1 and ABI1. The activation of PLD in response to the ABA action results in the formation of secondary messengers of signaling cascades. Knockout of $P L D \alpha 1$ gene prevents from the accumulation of active oxygen forms (hydrogen peroxide) and nitrogen oxide, caused by ABA in stomata cells. The activity of NADPH-oxidase, catalyzing the formation of hydrogen peroxide in response to ABA, is inhibited in these transgenic plants. Hydrogen peroxide and donor of nitrogen oxide, introduced exogeneously, stimulate stomata closure in both transgenic and wild type plants [17]. These results testify to the fact that ABA along with activation of $P L D \alpha 1$ causes the formation of phosphatidic acids. In their turn, they mediate the activation of signaling cascade of heterotrimeric G-proteins, which blocks stomata opening, and inhibit protein phosphatase ABI1 and stimulate accumulation of 
hydrogen peroxide and nitrogen oxide, causing stomata closure.

The expression of genetic construction, containing anti-sense sequence of $P L D \beta 1$ gene of rice, neutralizes seed dormancy, caused by ABA. An analysis of expression of the response genes to $\mathrm{ABA}$ in these transgenic plants revealed that $P L D \beta 1$ is a stimulator of ABA signal transmission. This becomes evident through the activation of SAPK8 and SAPK10 expression as well as the decrease in the levels of transcripts of inducers of GAmyb and $\alpha$-amylase germination. This mechanism is assumed to promote the inhibition of seed germination [4]. Gibberellins stimulate the seeds to leave quiescence, in other words, they act in this process as ABA antagonists. Rice plants with $P L D \beta 1$ deficiency are characterized by increased sensitivity to gibberellins [4]. ABA inhibits cell division [21] and activates organ senescence [14]. In Arabidopsis mutants, which are PLD $\alpha 1$ and PLD $\alpha 4$ genes knockout, contrary to the mutants of $P L D \beta 1$ and $P L D \delta 1$, the negative action of ABA on the expression of $K u$ gene is neutralized. The product of this gene plays a positive role in processes of DNA restoration and replication [22]. The expression of anti-sense construction of $P L D \alpha 1$ suppresses senescence of leaves, induced by ABA [23].

Phospholipase D mutants in the analysis of mechanisms of ethylene and auxin action on metabolism of plant cells. Ethylene plays a key role in the plants response to stresses [24] and in the induction of fruit ripening [25]. Suppression of senescence was registered in the leaves of Arabidopsis plants, where antisense construction of $P L D \alpha 1$ gene is expressed [23]. These mutants have PLDв and PLDг activity of wild type plants, which proves that the absence of functioning $P L D \alpha$ gene is not compensated by the presence of PLDв and PLDг in cells. Therefore, PLD61 is a determining factor in the realization of ethylene action on senescence of leaves. On the other hand, the expression of antisense construction of $P L D \alpha 1$ gene in tomatoes causes the delay in ethylene evolution and suppression of the process of fruit ripening [26].

Auxins regulate the development of vessels, gravitropism of roots, as well as division and growth of cells [27]. PLD 2 2-deficient plants are less sensitive to auxin; they are characterized by inhibited gravitropism of roots and auxin-dependent growth of hypocotyls, while an opposite phenotype was registered upon overexpression of the gene of mentioned isoenzyme which testifies to the positive role of $P L D \zeta 2$ in reactions of plant metabolism on the action of auxin. Both the level of expression of early response genes to auxin and the activity of sensitive promoter DR5-GUS decrease in knockout or $P L D \zeta 2$-deficient plants and increase at artificial intensification of $P L D \zeta 2$ expression. It proves a role of PLD $\zeta 2$ in the realization of the auxin action in plant cells [28]. The transport of intracellular vesicles, filled with auxin, is blocked in PLD 32 -deficient plants, but it is stimulated at artificial increase in the expression of $P L D \zeta 2$ gene [28]. Protein PIN2 participates in polar transport of auxin as a phytohormone transporter and is significant for regulation of gravitropism of roots [29]. Cyclic stream of PIN2-containing vesicles in cells is blocked in $P L D \zeta 2$-deficient plants, but intensified in roots with artificially enhanced expression of the gene of this isoenzyme. However, genetic manipulations with $P L D \zeta 2$ do not affect polar localization of PIN2 [28]. As $P L D \zeta 2$ gene knockout causes only partial weakening of cell response to auxin (contrary to notable sensitivity loss in the mutants of transduction of this phytohormone signal), PLD 22 may influence the auxin signaling indirectly due to regulation of its transport in plants [28]. In apexes of roots PLD $\zeta 2$ plays a key role as a modulator of transport of this phytohormone. Auxin translocation is inhibited by $40 \%$ in $P L D \zeta 2$ mutants, but increases by $30 \%$ in case of artificial enhancing in the level of expression of $P L D \zeta 2$ gene [30].

Genetic manipulations with phospholipase D in research on the mechanisms of impact of oxidative stress and tissues wounding. Accumulation of active forms of oxygen in cells takes place in response to the action of various biotic and abiotic stresses [31]. The expression of antisense construction of $P L D \alpha 1$ gene of Arabidopsis blocks the formation of superoxide radicals, catalyzed by NADPH-oxidase, while PA, applied in exogenous way, stimulate this reaction in the leaves of the mentioned plants [32]. On the other hand, the protoplasts and leaves of plants, which are PLD $\delta$ gene knockout, are characterized by increased sensitivity to hydrogen peroxide. An increase in the 
level of PA and phosphatidylbutanol as well as the activity of $49 \mathrm{kDa}$ MAP-kinases under the influence of hydrogen peroxide are inhibited in plants, which are $P L D \delta$ knockout. Moreover, the viability of plants at ultraviolet irradiation, stimulating the formation of hydrogen peroxide, decreases sharply at $P L D \delta$ gene knockout [33].

Therefore, isoenzymes of PLD participate in response to reactive oxygen forms: PLD $\alpha 1$ stimulates their formation, while РLDд provides metabolism reaction in response to their action.

In Arabidopsis with the expression of antisense construction of $P L D \alpha 1$ gene, the cell wounding as a stress factor causes inhibition of the formation of PA and jasmonic acid, as well as the expression of gene of LOX2 lipoxigenase [34].

Moreover, local accumulation of PA and increase in the PLD activity in the leaves of plants, destroyed due to wounding, are completely eliminated in double knockout mutants $P L D \alpha 1 / P L D \delta$. Knockout of $P L D \alpha 1$ and $P L D \delta$ genes testifies to a significant role of these isoenzymes in PA accumulation, conditioned by the wounding. However, the expression of LOX2 gene, levels of jasmonic acid and its predecessors, as well as the activity of MAP-kinases do not change in double mutants $P L D \alpha 1 / P L D \delta$ [35], which does not confirm the significance of these isoenzymes for abovementioned defence reactions of metabolism of plant cells to the wounding.

Isoforms of phospholipase $\mathrm{D}$, participating in the realization of signaling at biotic stresses. Sensitivity and resistance of plants to specific pathogens depend on the plants recognition abilities [36]. The role of PLD in the mechanisms of plant interaction with pathogens was studied in tomatoes with $P L D \beta 1$ gene knockdown. It was revealed that in response to the action of xylanase elicitor the mentioned isoenzyme is a negative regulator of the formation of reactive oxygen species, but a positive regulator of the expression of gene of $\beta$-D-xylosidase, which is an enzyme, participating in restructuring of plant cellular wall [37]. However, in the absence of infection the knockdown of $P L D \beta 1$ gene of rice determines activation of defence reactions of plants, i.e. accumulation of reactive oxygen species and induction of expression of defensive response genes
(PR-1, PR-4, B-glucanases, chitinases, traumatin-like protein, transcription factors of WRKY and ERF families). Death of the cells, specific for hypersensitivity reaction, as well as biosynthesis of phytoalexins and increase in resistance to pathogens Pyricularia grisea fungi and Xathonomonas oryzae bacteria -were registered in these transgenic plants [38]. These data testify to the role of PLD $\beta 1$ as a negative regulator of defensive reactions and resistance of plants at under normal growth conditions and as a positive one- at pathogens action.

The analysis of metabolism reaction of cells to cold stress on the example of Arabidopsis plants, transgenic in phospholipase $D$ genes. Twice-weakened formation of PA, caused by freezing, was revealed in the plants, expressing antisense construction of $P L D \alpha 1$ gene, which is also specific for phosphatidylcholine breakdown. Increase in the resistance to freezing was registered for PLD $\alpha 1$-deficient plants [39].

On the contrary, isoenzyme $\operatorname{PLD} \delta$, bound to plasmatic membranes, promotes resistance increase of Arabidopsis to freezing. Gene knockout of this PLD isoenzyme causes sharp decrease in plant resistance to cold, while artificial enhancement of the expression of $P L D \delta$ gene increases freezing tolerance of plants [40]. Contrary to PLD $\alpha 1$, PLD $\delta$ does not promote mass decomposition of membrane lipids, but causes formation of PA, performing a signaling function in the adaptation of cell metabolism to low temperatures. Plants, which are $P L D \delta$ gene knockout, grow and develop at under normal conditions without evident changes $[40,41]$. On the other hand, these transgenic plants are more sensitive to the oxidative stress [33].

PLD $\alpha 1$ plays a key role in the process of hydrolysis of phosphatidylglycerol of plastids, while PLDд functions as a negative regulator of decomposition of plastid lipids and PA accumulation under these conditions [42]. PLD are the modulators of expression of genes of plant tolerance to cold. Artificial expression of antisense construction of $P L D \alpha 1$ results in the increase in resistance to freezing in both acclimatized and non-acclimatized Arabidopsis plants. The activation of expression of physiological response genes to low temperatures - COR 47 and COR78 - was not revealed in non-acclimatized $P L D \alpha 1$-deficient 
plants. However, intense expression of COR47 and COR78 genes as well as increase in the osmolytes level were revealed in $P L D \alpha 1$-deficient plants at conditions of acclimatization to low temperatures and especially to freezing [43]. Still, at low temperatures PLD knockout does not change the expression of COR genes, providing resistance to freezing. PLD $\delta$ also forms PA, weakening cell damage, caused by oxidative stress at low temperatures.

The role of PLD in the mechanisms of regulation of plant cell metabolism in response to the action of heat shock has not been fully specified yet. The increase in environment temperature to $40^{\circ} \mathrm{C}$ results in rapid increase in PA levels in cultures of tobacco cells, Arabidopsis sprouts and rice leaves. It is partially mediated by the activation of phospholipase D - the amount of phosphatidylbutanol is sharply increased at early stages of heat shock action [44]. The abovementioned testifies to the significance of PLD for the transduction of the stress signal in plant cells. However, PLD isoenzymes, activated under the influence of heat shock, are still unknown.

Lipid signaling at osmotic stress. $P L D \alpha 1$ gene knockout in Arabidopsis increases sensitivity of plants to drought. Changes in expression of various genes, coding enzymes of metabolism and transduction of phytohormone signals were revealed at stress conditions [45]. Gene knockout or expression of antisense $P L D \alpha 1$ construction in Arabidopsis results in inhibition of sensitivity of plants to abscisic acid, weakening of stomata closure, and increase in water loss after transpiration $[15,16,23]$. At the same time, artificially intensified expression of $P L D \alpha 1$ gene increases susceptibility of plants to ABA action $[15,16]$. PLD $\alpha 1$ play a positive role in the induction of closure of guard cell aperture in response to $\mathrm{ABA}$ and in the decrease in water loss of plants after transpiration $[16,18]$.

According to the results of phenotype analysis of knockout mutants, $P L D \alpha 1$ is a modulator of various reactions of plants to drought. This isoenzyme plays the role of stimulator of stomata closure at early stages of the mentioned stress [46]. On the other hand, knockout or overexpression of $P L D \alpha 3$ gene does not influence the transpiration level [47] which testifies against the possibility of participation of this PLD isoenzyme in the regulation of dynamics of guard cell aperture in response to the action of abscisic acid. Moreover, the biosynthesis of this phytohormone does not change in $P L D \alpha 3$ knockout plants [47]. ABA plays the role of a positive regulator of hydrotropism of plant roots. $P L D \xi 2$ gene knockout violates and prevents hydrotropism of roots in Arabidopsis. Drought and abscisic acid, the accumulation of which is conditioned by this stress, stimulate the activity of $P L D \xi 2$ promoter in root cap and block gravitropism of roots [48]. Contrary to $P L D \alpha 1$ gene mutants, the level of accumulation of PA and phosphatidylbutanol in transgenic Arabidopsis plants with antisense PLD $\delta$ construction decreases at dehydration conditions, which demonstrates the significance of PLD $\delta$ for the formation of PA at the mentioned stress. However, notable changes in phenotype at both normal conditions and dehydration were registered neither in wild type plants nor in plants with PLD gene in antisense orientation [41]. On the other hand, PLD $\delta$ gene knockout in Arabidopsis increases the sensitivity of plants to salt stress [49]. Therefore, PLD61 and PLDд play their own roles in the process of cellular transmission of information about the conditions of water potential in the environment. Combined knockout of $P L D \alpha 1$ and $P L D \delta$ genes causes the decrease in resistance of root growth to salt and hyperosmotic stresses. The double mutants of Arabidopsis PLD $\alpha 1 / P L D \delta$ are characterized by more evident sensitivity to salt stress compared to the gene mutants of each of these PLD isoenzymes. Knockout of $P L D \alpha 1$ or $P L D \delta$ gene causes partial decrease in the level of PA, stimulated by salt stress, while at simultaneous knockout of both genes PA accumulation is only one-third compared to wild type plants [49]. The final formation of phosphatidylbutanol and PA was revealed at conditions of salt stress and dehydration in the double mutants [49] which testifies to the participation of other PLD isoenzymes (presumably PLD 33 [47]) in the realization of the action of these stresses on plants. Moreover, PLDв 1 isoenzyme may also participate in reactions of plant cells to osmotic stress as rice with deficiency of the gene of this enzyme is characterized by increased sensitivity to high concentrations of salts [4].

PLD 23 plays an absolutely different role in the regulation of growth of plants at conditions of 
hyperosmotic stress. PLD $\alpha 3$ knockout Arabidopsis is characterized by intense expression of response genes to abscisic acid and increased sensitivity to salt stress and dehydration, while artificial increase in the expression level of gene of the mentioned isoenzyme increases plant resistance to these stresses. At this isoenzyme gene knockout the growth of roots is more inhibited under the influence of ABA contrary to the wild type plants. Artificially intensified expression of $P L D \propto 3$ at the conditions of salt stress results in the increase in the number of side roots, acceleration of seed germination, growth of sprouts and roots. The growth of these transgenic plants is more expressed compared to the wild type at long-term salt stress [47]. Artificial changes in $P L D \alpha 3$ expression at the conditions of salt stress and water deficiency are respectively reflected at the levels of $\mathrm{PA}$ and gene expression (TOR and $A G C 2$ ), the products of which are modulators of growth processes in response to the incoming nutrients and action of stresses. The state of phosphorilation of protein of ribosomal protein kinase S6K changes as well [47]. Therefore, PLD $\alpha 1$ and $P L D \propto 3$ participate in the modulation of response of plants to the action of osmotic stress due to various mechanisms: PLD $\alpha 1$ mediates the action of abscisic acid on dynamics of guard cell aperture to decrease the level of water loss by plants, while PLD63 causes the growth of roots in response to the action of salt stress and drought to enlarge the surface of water absorption.

The analysis of phenotype of plants at knockout and artificially intensified expression of $P L D \varepsilon$ gene testifies to the fact that PLD $\varepsilon$ stimulates the growth of Arabidopsis roots at the conditions of hyperosmotic stress, induced by water deficiency and high concentrations of salts. At the same time PLD $\varepsilon$ may have a key role in the mechanisms of plant perception of the state of provision with nutrients, mineral nitrogen, first and foremost [50].

Participation of PLD in the regulation of various stages of plant ontogenesis. PA, the product of PLD activity, is the central mediator of the biosynthesis of phospholipids [51]. High temperature and humidity as well as long-term storing accelerate ripening of seeds. However, knockout or knockdown of PLD 1 gene in Arabidopsis stimulates their germination, blocks the decrease in the number of unsaturated fatty acids and decreases the level of accumulation of peroxide forms of lipids, thus improving quality of seeds. Sprouts of these transgenic plants grow faster and have longer roots and larger leaves. $P L D \alpha 1$ knockdown also causes plant seeds to lose their capability of ripening compared to plants, which are knockout of this isoenzyme gene, observed as the increase in their viability $[52,53]$. On the other hand, artificial violation of the formation of functional protein PLD $\delta$ promotes ripening of seeds and increases their germination capability [52].

The role of PLD in the regulation of reproductive process in plants has not been studied well enough. Artificially intensified expression of $P L D \alpha 1$ gene in Arabidopsis does not influence the formation of flowers. No differences in the number of seeds and pods compared to wild type were found in plants with the expression of antisense construction of this gene [23]. The flowers of plants, expressing antisense construction of PLD $\alpha 1$ gene, contain only $10 \%$ of activity of the wild type PLD which evidences to self-sufficiency of the activity of other PLD isoenzymes to support normal development of abovementioned reproductive organs. These plants are characterized by the activity of PLD $\beta$ and PLD $\gamma$. However, the absence of reliable changes in seed formation [23] testifies to non-participation of PLD61 in reproduction of plants. On the other hand, according to the researches on phenotype of knockout plants, PLD61 participates in the formation of a basic level of PA in flowers, pedicles, seeds, but not pods of Arabidopsis [53]. Contrary to the wild type plants, the plants with overexpressed $P L D \alpha 3$ are notable for early formation of flowers, seeds, and increased number of pods only at conditions of moderate drought. An absolutely opposite phenomenon was revealed at $P L D \propto 3$ gene knockout. The expression of genes, coding the factors of induction of flower formation (TSF, BFT), is enhanced at artificial increase in the level of $P L D \alpha 3$ expression at the conditions of water deficiency, but decreases in plants, which are $P L D \alpha 3$ knockout. At normal conditions the expression of TSF gene only decreases at $P L D \alpha 3$ knockout compared to wild type plants [47].

It was shown that PLDж1 participates in the regulation of morphogenesis of root hair. Artificial 
intensification of $P L D \xi 1$ gene expression causes the formation and enlargement of branching of ectopic root hair. The expression of antisense $P L D \xi 1$ construction results in violation of localization, growth, and development of root hair, not influencing their laying. $\operatorname{PLD} \xi 1$ is assumed to regulate the growth and development of roots, modulating the processes of membrane transport, in particular, exocytosis [54]. Different data were obtained at $P L D \xi$ genes knockout. Localization of root hair has no evident changes in plants, which are $P L D \xi 1$ and $P L D \xi 2$ genes knockout, while extremely weak changes in the mentioned phenotype were revealed on apexes of roots at the conditions of low content of mineral phosphorus [55]. One of the probable reasons of differences in the results of these researches may be experiment conditions: the system of induced repression of $P L D \xi 1$ gene was used in the first case [54], and a knockout - in the second [55]. It is possible that blockade of PLD $\xi 1$ with the expression of antisense construction of the respective gene is not specific for PLD $\xi 1-$ other PLD isoenzymes may also be repressed in this case.

The second reason of differences in the results is the fact that a definite threshold of PLD $\xi 1$ protein levels is required for laying and growth of root hair, while the expression of antisense construction of this gene may neutralize these parameters in cells only partially. However, PLD $\xi$ may be significant for the regulation of growth of roots in response to stressful conditions of environment. The growth of primary roots at conditions of low concentrations of mineral phosphorus in the incubation medium in Arabidopsis plants, which are simultaneously knockout of $P L D \xi 1$ and $P L D \xi 2$, is inhibited compared to the wild type plants or the plants, knockout of one of $P L D \xi$ genes. The growth of lateral roots increases in the double mutants and localization of the formation of root hair does not change. PLD 22 knockout decreases the level of PA accumulation in the roots at the conditions of mineral phosphorus deficiency [55]. The morphology of root meristem at low content of phosphorus is sharply violated in the plants, which are $P L D \xi 2$ gene knockout, that reflects on the growth of primary roots and root hair [56].

On the other hand, the growth of roots at knockout of PLD 1 and PLD $\alpha$ genes of Arabidopsis does not change significantly [49], PLD $\alpha 1$ may participate in the formation of the basic level of PA in Arabidopsis roots [53]. Therefore, PLD $\xi 1$ and PLD $\xi 2$ simultaneously play the key role in the regulation of growth of roots in response to conditions of mineral phosphorus deficiency.

PLD $\varepsilon$ is a stimulator of the growth of lateral roots and accumulation of biomass in plants [50]. At artificially intensified expression of $P L D \varepsilon$ gene, the lateral roots grow faster compared to the wild type plants, while $P L D \varepsilon$ knockout suppresses growth of roots. The number and growth of cells increase at artificially intensified expression of $P L D \varepsilon$ gene. The surface area of lamina, growth of leaf cells, number of leaves and their cells, as well as the number of seeds increase in these transgenic plants, but decrease at $P L D \varepsilon$ gene knockout. Plant sprouts grow faster at overexpression of $P L D \varepsilon$ gene, but grow slower in knockout plants compared to the wild type plants. The levels of PA content increase in leaves and roots upon overexpression of the gene of this isoenzyme, decreasing in the knockout plants [50].

The violation of membrane integrity is one of the main reasons of induction of senescence processes [57]. Contrary to the wild type plants, the leaves of plants, where antisense construction of $P L D \alpha 1$ gene is expressed, are characterized by weakening in senescence features, conditioned by abscisic acid and ethylene [23]. ABA and ethylene play a significant role in reactions of plants to the action of stresses increasing biosynthesis of these phytohormones [58, 59]. Therefore, catabolism of membrane lipids, performed by PLD $\alpha 1$, may be the result of response to stresses, and not the reason of natural senescence.

The role of PLD in the processes of growth and ripening of fruit may be revealed in the regulation of metabolism of their cells [60]. Tomato fruits, where antisense construction of $P L D \alpha 1$ gene is expressed, are smaller in size compared to those of the wild type plants, they are kept longer, are harder and notable for delayed climacteric evolution of ethylene [26].

Therefore, various isoenzymes of PLD participate in the regulation of growth and development of plants.

Conclusions. The results of recent researches using transgenic plants have significantly extended the ideas on the mechanisms of realization PLD-induced signals 


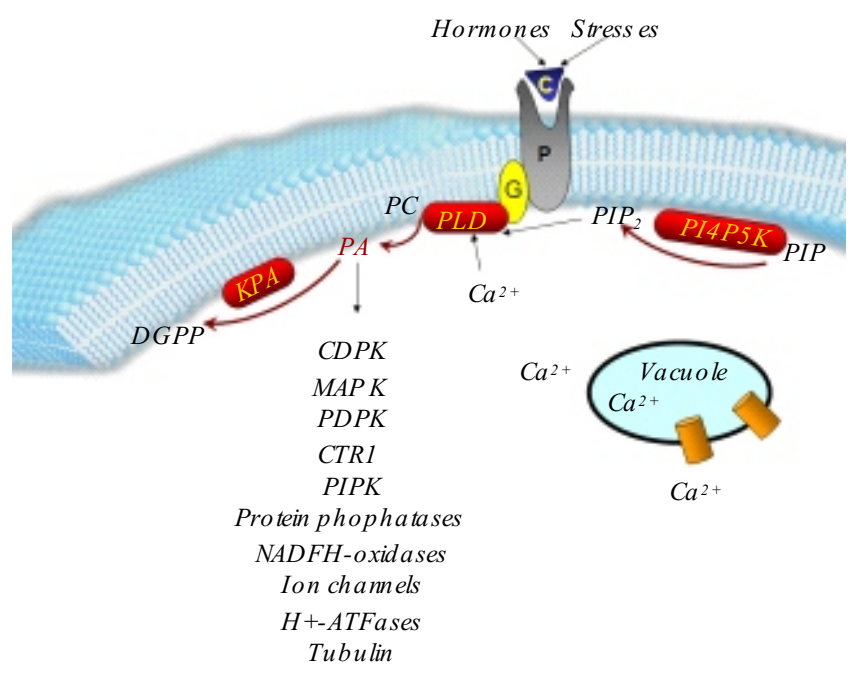

Fig. 2. Functioning of phospholipase D (PLD) in signaling cascades of plant cells: DGPP - diacylglycerolpyrophosphate; CDPK - calcium-dependent protein kinases; KPA - kinases of phosphatidic acid; MAPK - mitogen-activated protein kinases; R - receptor; S stimulus; CTR1 - similar to Raf serine/threonine protein kinase (negative regulator of ethylene signaling); PDPK phosphoinositide-dependent protein kinases; PIPK - kinase of phosphatidylinositolphosphate; PIP - phsophatidylinositolmono-p hosphate; $\mathrm{PIP}_{2}$ - phosphatidylinositolbisphosphate; PI4P5K phosphatidylinositol-4-phosphate-5-kinase; PA - phosphatidic acid; PC - phosphatidylcholine; G - heterotrimeric G-protein

in the cell (Fig. 2). A wide spectrum of PLD isoenzymes in plants provides the formation of various types of phosphatidic acids in specific organs and cells in the process of their development at the action of external stimuli. This ensures the variety of PA functions in plants, since it is a secondary messenger of signaling cascades, modulating the activity of key enzymes in response to the action of stresses (osmotic, cold, oxidative) and phytohormones (ABA, auxins, cytokinins, and ethylene). At the same time little progress has been achieved in the understanding of the interaction of PLS and PLD and the role of diacylglycerolkinases in PA synthesis. It is also important to analyze the nature of PA interaction with the targets of signaling systems, the recognition of which is possible with the elaboration of a biosensor for PA determination, combining a specific factor of PA binding with fluorescent protein. The application of the biosensor would allow obtaining the information about components of signaling systems of lipid nature and their role in the coordination of intensity and direction of cell metabolism, as well as in the realization of genetic programmes of plant growth and development.

The work was supported by the grants of NAS of Ukraine (2.1.10.32-10), State Fund of Fundamental Research of Ukraine (No. F29.4/019) and State Fund of Fundamental Research of Belarus (B09K-061).

В. С. Кравеи, Я. С. Колесников, С. В. Кретинин, Е. М. Кабачевская, Г. В. Ляхнович, О. М. Бондаренко, И. Д. Волотовский, В. П.Кухарь

Молекулярные и генетические подходы к исследованию роли фосфолипазы D клеток растений

Резюме

Обзор посвящен анализу работ в области исследования роли фосфолипазы $D$ в регуляции метаболизма клеток растений. Анализ работ, проведенных с использованием молекулярных и генетических подходов, позволяет судить о ФЛD как о важном компоненте сигнальных систем ряда гормонов и стрессов.

Ключевые слова: фосфолипаза D, фосфатидная кислота, трансгенные растения.

В. С. Кравець, Я. С. Колесников, С. В. Кретинін, О. М. Кабачевська, Г. В. Ляхнович, О. М. Бондаренко, І. Д. Волотовський, В. П. Кyxap

Молекулярні і генетичні підходи до вивчення ролі фосфоліпази D клітин рослин

Резюме

Огляд присвячено аналізу робіт у площиині дослідження ролі фосфоліпази D в регулячії метаболізму клітин рослин. Аналіз робіт, виконаних з використанням молекулярних та генетичних підходів, свідчить на користь ФЛD як важливого компонента сигнальних систем низки гормонів і стресів.

Ключові слова: фосфоліпаза D, фосфатидна кислота, трансгенні рослини.

\section{REFERENCES}

1. Pappan K., Austin-Brown S., Chapman K. D., Wang X. Substrate selectives and lipid modulation of plant phos pholipase $\mathrm{D} \alpha,-\beta$, and $-\gamma / /$ Arch. Biochem. Biophys. $-1998 .-353, \mathrm{~N} 1 .-$ P. 131-140.

2. Oblozinsky M., Ulbrich-Hofmann R., Bezakova L. Head group specificity of phospholipase D isoenzymes from poppy seedlings (Papaver somniferum L.) // Biotechnol. Lett.-2005.27, N 3.-P. 181-185. 
3. Elias M., Potocky M., Cyrckova F., Zarsky V. V. Molecular diversity of phospholipase D in angiosperms // BMC Genomics.-2002.-3, N 1.-P. 2.

4. Li G., Lin F., Xue H.-W. Genome-wide analysis of the phospholipase D family in Oryza sativa and functional characterization of PLDв 1 in seed germination // Cell Res.-2007.-17, N 10.-P. 881-894.

5. Hanahan D. J., Chaikoff I. L. A new phospholipid-splitting enzyme specific for the ester linkage between the nitrogenous base and the phosphoric acid grouping // J. Biol. Chem.1947.-169, N 1.-P. 699-705.

6. Liscovitch M., Czarny M., Flucci G., Tang X. Phospholipase D: molecular and cell biology of a novel gene family // Biochem. J.-2000.-345, N 3.-P. 401-415.

7. Wang X., Devaiah S.P., Zhang W., Welti R. Signaling functions of phosphatidic acid // Progr. Lipid Res.-2006.-45, N 3.-P. 250-278.

8. Wang $X$. Regulatory functions of phospholipase D and phosphatidic acid in plant growth, development, and stress responses // Plant Physiol.-2005.-139, N 2.-P. 566-573.

9. Bargmann B. O., Munnik T. The role of phospholipase D in plant stress responses // Curr. Opin. Plant Biol.-2006.-9, N 5.-P. 515-522.

10. Romanov G. A. How do cytokinins affect the cell? // Rus. J. Plant Physiol.-2009.-56.-P. 268-290.

11. Romanov G. A., Kieber J. J., Schmblling T. A rapid cytokinin response assay in Arabidopsis indicates a role for phospholipase D in cytokinin signaling // FEBS Lett.-2002.-515, N 1-3.-P. 39-43.

12. Kravets V. S., Kretinin S. V., Kolesnikov Ya. S., Getman I. A., Romanov G. A. Cytokinins evoke rapid activation of phospholipase D insensitive plant tissues // Dokl. Biokhim. Biophys.-2009.-28, N 5.- P. 1-4.

13. Kravets V. S., Kolesnikov Ya. S., Kretynin S. V., Getman I. A., Romanov $G$. A. Rapid activation of specific phospholipase(s) D by cytokinin in Amaranthus assay system // Physiol. Plantar.-2010.-138.-P. 249-255.

14. Amini A., Glevarec G., Andreu F., Reverdiau P., Rideau M., Creche $J$. Effects of phosphatidic acid on cytokinin signal transduction in periwinkle cells // J. Plant Growth Regul.2008.-27, N 4.-P. 394-399.

15. Tarasova $O$. V., Medvedev S. S. Influence of benzylamino-. purine on fatty acid composition and ratio of phospholipids from maize coleoptiles and roots (in Russian) // Vestn. S.-Petersb. Univ.-2008.-3, N 2.-P. 85-90.

16. Zhang $W$., Qin C., Zhao J., Wang X. Phospholipids D $\alpha 1$-derived phosphatidic acid interacts with ABI1 phosphatase $2 \mathrm{C}$ and regulates abscisic acid signaling// Proc. Nat. Acad. Sci. USA.-2004.-101, N 25.-P. 9508-9513.

17. Zhang Y., Zhu H., Zhang Q., Li M., Yan M., Wang R., Wang L., Welti R., Zhang W., Wang $X$. Phospholipase D $\alpha 1$ and phosphatidic acid regulate NADPH oxidase activity and production of reactive oxygen species in ABA-mediated stomatal closure in Arabidopsis // Plant Cell.-2009.-21, N 8.P. 2357-2377.

18. Mishra G., Zhang W., Deng F., Zhao J., Wang X. A bifurcating pathway directs abscisic acid effects on stomatal closure and opening in Arabidopsis // Science.-2006.-312, N 5771.-P. 264-266.

19. Lein $W$., Saalbach $G$. Cloning and direct G-protein regulation of phospholipase D from tobacco // Biochim. Biophys. Acta.2001.-1530, N 2-3.-P. 172-183.
20. Zhao J., Wang X. Arabidopsis phospholipase D $\alpha 1$ interacts with the heterotrimeric G-protein $\alpha$-subunut through a motif analogous to the DRY motif in G-protein-coupled receptors // J. Biol. Chem.-2004.-279, N 3.-P. 1794-1800.

21. Mahajan A., Sharma S. Antagonistic effect of polyamines on ABA-induced suppression of mitosis in Allium cera L. // Ind. J. Exp. Biol.-2009.-47, N 2.-P. 136-139.

22. Liu P. F., Chang W. C., Wang Y. K., Chang H. Y., Pan R. L. Signaling pathways mediating the suppression of Arabidopsis thaliana $K u$ gene expression by abscisic acid // Biochim. Biophys. Acta.-2008.-1779, N 3.-P. 164-174.

23. Fan L., Zheng S., Wang X. Antisense suppression of phospholipase $\mathrm{D} \alpha$ retards abscisic acid- and ethylene- promoted senescence of postharvest Arabidopsis leaves // Plant Cell.1997.-9, N 12.-P. 2183-2196.

24. Chen H., Xue L., Chintamanani S., Germain H., Lin H., Cui H., Cai R., Zuo J., Tang X., Li X., Guo H., Zhou J. M. ETHYLENE INSENSITIVE3 and ETHYLENE INSENSITIVE3LIKE1 repress SALICYLIC ACID INDUCTION DEFICIENT2 expression to negatively regulate plant innate immunity in Arabidopsis // The Plant Cell.-2009.-21, N 8.P. 2527-2540.

25. Bapat V. A., Trivedi P. K., Ghosh A., Sane V. A., Ganapathi T. $R$., Nath $P$. Ripening of fleshy fruit: molecular insight and the role of ethylene // Biotechnol. Adv.-2010.-28, N 1.-P. 94107.

26. Pinhero R. G., Almquist K. C., Novotna Z., Raliyath G. Developmental regulation of phospholipase D in tomato fruits // Plant Physiol. and Biochem.-2003.-41, N 3.-P. 223-240.

27. Woodward A. W., Bartel B. Auxin: regulation, action, and interaction // Ann. Bot. (Lond.).-2005.-95, N 1.-P. 707-735.

28. Li G., Xue H.-W. Arabidopsis PLDz2 regulates vesicle trafficking and is required for auxin response // The Plant Cell.2007.-19, N 1.-P. 281-295.

29. Abas L., Benjamins R., Malenica N., Paciorek T., Wisniewska J., Jeanette C., Moulinier-Anzola J. C., Sieberer T., Friml J., Luschnig C. Intracellular trafficking and proteolysis of the Arabidopsis auxin-efflux facilitator PIN2 are involved in root gravitropism // Nat. Cell Biol.-2006.-8, N 3.-P. 249-256.

30. Mancuso S., Marras A., Muguai S., Schlicht M., Zarsky V., Li G., Song L., Xue H. W., Baluska F. Phospholipase D $\zeta 2$ drives vesicular secretion of auxin for its polar cell-cell transport in the transition zone of the root apex // Plant Signal. and Behavior.-2007.- 2, N 4.-P. 240-244.

31. Apel K., Hirt H. Reactive oxygen species: metabolism, oxidative stress, and signal transduction // Annu. Rev. Plant Biol.2004.-55.-P. 373-399.

32. Sang Y., Cui D., Wang X. Phospholipase D and phosphatidic acid mediated generation of superoxide in Arabidopsis // Plant Physiol.-2001.-126, N 4.-P. 1449-1458.

33. Zhang W., Wang C., Qin C., Wood T., Olafsdottir G., Welti $R$., Wang $X$. The oleate-stimulated phospholipase D, PLD $\delta$, and phosphatidic acid decrease $\mathrm{H}_{2} \mathrm{O}_{2}$-inducrd cell death in Arabidopsis // The Plant Cell.-2003.-15, N 10.-P. 22852295.

34. Wang C., Zien C. A., Afitlhill M., Welti R., Hildebrand D. F., Wang $X$. Involvement of phospholipase D in wound-induced accumulation of jasmonic acid in Arabidopsis // The Plant Cell.-2000.-12, N 11.-P. 2237-2246.

35. Bargmann B. O., Lazalt A. M., Riet B., Testerink C., Merquiol E., Mosblech A., Reyes A. L., Pieterse C. M., Haring M. A., Heilmann I., Bartels D., Munnik T. Reassessing the role of 
phospholipase D in the Arabidopsis wounding response // Plant Cell Environ.-2009.-32, N 7.-P. 837-850.

36. Nimchuk Z., Eulgem T., Holt B. F., Dangl J. L. Recognition and response in the plant immune system // Annu. Rev. Genet.-2003.-37.-P. 579-609.

37. Bargmann B. O. R., Laxalt A. M., ter Riet B., Schouten E., van Leeuwen W., Dekker H. L., de Koster C. G., Haring M. A., Munnik $T$. LePLD $\beta 1$ activation and relocalization in suspension-cultured tomato cells treated with xylanase // The Plant J.-2006.-45, N 3.-P. 358-368.

38. Yamaguchi T., Kuroda M., Yamakawa H., Ashizawa T., Hirayae K., Kurimoto L., Shinya T., Shibuya N. Suppression of a phospholipase D gene, OSPLD $\beta 1$, activates defense responses and increases disease resistance in rice // Plant Physiol.2009.-150, N 1.-P. 308-319.

39. Welti R., Li W., Li M., Sang Y., Biesiada H., Zhou H.-E., Rajashekar C. B., Williams T. D., Wang X. Profiling membrane lipids in plant stress responses. Role of phospholipase D $\alpha$ in freezing-induced lipid changes in Arabidopsis // J. Biol. Chem.-2002.-277, N 35.-P. 31994-32002.

40. Li W., Li M., Zhang W., Welti R., Wang X. The plasma membrane-bound phospholipase $\mathrm{D} \delta$ enhances freezing tolerance in Arabidopsis thaliana // Nat. Biotechnol.-2004.-22, N 4.P. 427-433.

41. Katagiri T., Takahashi S., Shonizaki K. Involvement of a novel Arabidopsis phospholipase D, AtPLD $\delta$, in dehydratation-inducible accumulation of phosphatidic acid in stress signaling // Plant J.-2001.-26, N 6.-P. 595-605.

42. Li W., Wang R., Li M., Li L., Wang C., Welti R., Wang X. Differential degradation of extraplastidic and plastidic lipids during freezing and post-freezing recovery in Arabidopsis thaliana // J. Biol. Chem.-2008.-283, N 1.-P. 461-468.

43. Rajashekar C. B., Zhoua H.-E., Zhanga Y., Li W., Wang X. Suppression of phospholipase $D \alpha 1$ induces freezing tolerance in Arabidopsis: Response of cold-responsive genes and osmolyte accumulation // J. Plant Physiol.-2006.-163, N 9.P. 916-926.

44. Mishkind M., Vermeer J. E. M., Darwish E., Munnik T. Heat stress activates phospholipase D and triggers $\mathrm{PIP}_{2}$ accumulation at the plasma membrane and nucleus // The Plant J.2009.-60, N 1.-P. 10-21.

45. Mane S. P., Vasquez-Robinet C., Sioson A. A., Heath L. S., Grene R. Early PLD $\alpha$-mediated events in response to progressive drought stress in Arabidopsis: a transcriptome analysis // J. Exp. Bot.-2007.-58, N 2.-P. 241-252.

46. Hong $Y$., Zheng $S$., Wang $X$. Dual functions of phospholipase $\mathrm{D} \alpha 1$ in plant response to drought // Mol. Plant.-2008.-1, N 2.-P. 262-269.

47. Hong Y., Pan X., Welti R., Wang X. Phospholipase D $\alpha 3$ is involved in the hyperosmotic response in Arabidopsis // The Plant Cell.-2008.-20, N 3.-P. 803-816.

48. Taniguchi Y. Y., Taniguchi M., Tsuge T., Oka A., Aoyama T. Involvement of Arabidopsis thaliana phospholipase D $\zeta 2$ in root hydrotropism through the suppression of root gravitropism // Planta.-2010.-231, N 2.-P. 491-497.

49. Bargmann B. O. R., Laxalt A. M., ter Riet B., van Schooten B., Merquiol E., Testerink C., Haring M.A., Bartels D., Munnik
$T$. Multiple PLDs required for high salinity and water deficit tolerance in plants // Plant Cell Physiol.-2009.-50, N 1.P. 78-89.

50. Hong Y., Devaiah D. P., Thamasandra B. N., Bahn S. C., Li $M$., Welti R., Wang $X$. Phospholipase $\mathrm{D} \varepsilon$ and phosphatidic acid enhance Arabidopsis nitrogen signaling and growth // Plant J.-2009.-58, N 3.-P. 376-387.

51. Schmid K. M., Ohlrogge J. B. Chapter 4. Lipid metabolism in plants // New Compr. Biochem.-2002.-36, N 1.-P. 93-126.

52. Devaiah S. P., Pan X., Hong Y., Roth M., Welti R., Wang X. Enhancing seed quality and viability by suppressing phospholipase D in Arabidopsis // The Plant J.-2007.-50, N 6. P. 950-957.

53. Devaiah S. P., Roth M. R., Baughman E., Li M., Tamura P., Jeannotte R., Welti R., Wang X. Quantitative profiling of polar glycerolipid species from organs of wild-type Arabidopsis and a PHOSPHOLIPASE Da1 knockout mutant // Phytochemistry.-2006.-67, N 17.-P. 1907-1924.

54. Ohashi Y., Oka A., Rodrigues-Pousada R., Possenti M., Ruberti I., Morelli G., Aoyama T. Modulation of phospholipids signaling by GLABRA in root-hair pattern formation // Science.-2003.-300, N 5624.-P. 1427-1430.

55. Li M., Qin C., Welti R., Wang X. Double knockouts of phospholipase $\mathrm{D} \zeta 1$ and $\zeta 2$ in Arabidopsis affect root elongation during phosphate-limited growth, but do not affect root hair patterning // Plant Physiol.-2006.-140, N 2.-P. 761-770.

56. Cruz-Ramirez A., Oropeza-Aburto A., Razo-Hernandez F., Ramirez-Chavez E., Herrera-Estrella L. Phospholipase D $\zeta 2$ plays an important role in extraplastidic galactolipid biosynthesis and phosphate recycling in Arabidopsis roots // Proc. Nat. Acad. Sci. USA.-2006.-103, N 17.-P. 6765-6770.

57. Bouvier-Nave P., Berna A., Noiriel A., Compagnon V., Carlsson A.S., Banas A., Stymne S., Schaller H. Involvement of the phospholipid sterol acyltransferase 1 in plant sterol homeostasis and leaf senescence // Plant Physiol.-2010.-152, N 1.P. 107-119.

58. Ikegami K., Okamoto M., Seo M., Koshiba T. Activation of abscisic acid biosynthesis in the leaves of Arabidopsis thalia$n a$ in response to water deficit // J. Plant Res.-2009.-122, N 2.-P. 235-243.

59. Hershkovitz V., Friedman H., Goldschmidt E. E., Feygenberg $O$., Pesis $E$. Induction of ethylene in avocado fruit in response to chilling stress on tree // J. Plant Physiol.-2009.-166, N 17.-P. 1852-1855.

60. Yuan H., Chen L., Paliyath G., Sullivan A., Murr D. P. Characterization of microsomal and mitochondrial phospholipase $\mathrm{D}$ activities and cloning of a phospholipase D alpha cDNA from strawberry fruits // Plant Physiol. and Biochem.2005.-43, N 6.-P. 535-547. 